\title{
Reassessing flood frequency for the Sussex Ouse, Lewes: the inclusion of historical flood information since AD 1650
}

\author{
N. Macdonald ${ }^{1}$, T. R. Kjeldsen ${ }^{2}$, I. Prosdocimi ${ }^{3}$, and H. Sangster ${ }^{1,4}$ \\ ${ }^{1}$ Department of Geography \& Planning, School of Environmental Sciences and Institute of Risk and Uncertainty, \\ The University of Liverpool, Liverpool, UK \\ ${ }^{2}$ Department of Architecture and Civil Engineering, University of Bath, Bath, UK \\ ${ }^{3}$ Centre for Ecology \& Hydrology, Wallingford, UK \\ ${ }^{4}$ Department of Geography, Edge Hill University, Ormskirk, UK
}

Correspondence to: N. Macdonald (neil.macdonald@liv.ac.uk)

Received: 16 September 2013 - Published in Nat. Hazards Earth Syst. Sci. Discuss.: 19 December 2013

Revised: 6 November 2013 - Accepted: 19 June 2014 - Published: 30 October 2014

\begin{abstract}
The application of historical flood information as a tool for augmenting instrumental flood data is increasingly recognised as a valuable tool. Most previous studies have focused on large catchments with historic settlements, this paper applies the approach to the smaller lowland system of the Sussex Ouse in southeast England. The reassessment of flood risk on the Sussex Ouse is pertinent in light of the severe flooding in October 2000 and heightened concerns of a perceived increase in flooding nationally. Systematic flood level readings from 1960 and accounts detailing past flood events within the catchment are compiled back to ca. 1750 . This extended flood record provides an opportunity to reassess estimates of flood frequency over a timescale not normally possible within flood frequency analysis. This paper re-evaluates flood frequency at Lewes on the Sussex Ouse downstream of the confluence of the Sussex Ouse and River Uck. The paper considers the strengths and weaknesses in estimates resulting from contrasting methods of analysis and their corresponding data: (i) single site analysis of gauged annual maxima; (ii) combined analysis of systematic annual maxima augmented with historical peaks of estimated magnitude; (iii) combined analysis of systematic annual maxima augmented with historical peaks of estimated magnitude exceeding a known threshold, and (iv) sensitivity analysis including only the very largest historical flood events. Use of the historical information was found to yield much tighter confidence intervals of risk estimates, with uncertainty reduced by up to $40 \%$ for the 100 -year return frequency event when historical information was added to the gauged data.
\end{abstract}

\section{Introduction}

The application of historical records in flood frequency analysis has expanded rapidly over the last couple of decades (Brázdil et al., 1999, 2012; Barriendos et al., 2003; England et al., 2003; Glaser and Stangl, 2003; Macdonald et al., 2006; McEwen and Werritty, 2007; Glaser et al., 2010) following several severely damaging floods since the early 1990s in the UK (Hannaford and Marsh, 2008) and mainland Europe (Kundzewicz et al., 1999; Szlávik, 2003; Ulbrich et al., 2003; Böhm and Wetzel, 2006; Bezzola and Hegg, 2007). These extreme events have led to heightened demands for flood risk assessments that can incorporate a greater understanding of past extreme events and the methods and data used for producing them, with historical records providing an accessible and detailed account of pre-instrumental flood events (Macdonald, 2012). The value of historical records is recognised in several countries, with recommendations for its use in flood risk assessment in Germany, Spain, the UK and USA among others, and it has become enshrined within European law (EU Floods Directive - 2007/60/EC). However, the application of historical information within flood frequency analysis is not a modern phenomenon, as both the Flood Studies Report (FSR) (NERC, 1975) and Potter (1978) encourage consideration of historical information in flood assessment, with the USGS long using historical events as a guide for the potential magnitude of extreme events (O'Connor and Costa, 2004; Stedinger and Cohn, 1986; Gaume et al., 2010). Studies incorporating historical information have often focused on large, single-channel 


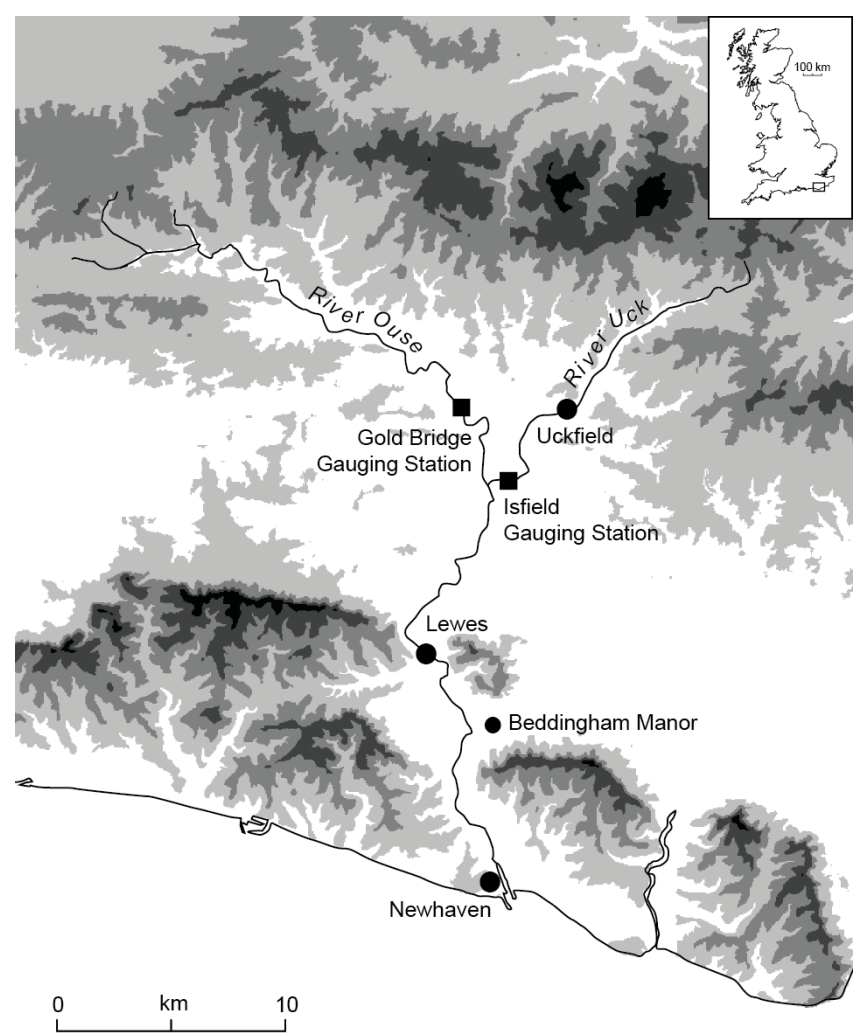

Figure 1. The area of the Sussex Ouse catchment.

lowland floodplain-dominated sites (e.g. Herget and Meurs, 2010), with long historical records arising from monastic, trade and/or political activities focused on urban centres (Macdonald et al., 2006). This study examines the flooding history of the Sussex Ouse and, in particular the area in and around the town of Lewes located in southern England (Fig. 1). In this area, the event of October 2000 flooded over 10000 properties and caused an estimated GBP 130 million in damages (Environment Agency, 2004), with a subsequent improvement in flood defences and development of a multiagency flood plan (Lewes District Council, 2010).

This paper reports the findings of a study exploring the benefits of incorporating historical information into flood frequency analysis at Lewes, and the associated implications on uncertainty. More specifically, the objectives of this paper are

1. to demonstrate the viability of incorporating historical information into flood frequency analysis

2. to consider the different approaches available and sensitivity to data availability on the Sussex Ouse

3. to examine the potential change in confidence (uncertainty) of derived flood estimates when incorporating historical records for extreme flood events ( $>100$ year return frequency), when compared to more conventional flood frequency analysis approaches.

\section{The Sussex Ouse catchment}

The Sussex Ouse flows south through the North Downs, Low Weald and South Downs out into the English Channel at Newhaven, past the principal settlements Haywards Heath, Uckfield and Lewes. The predominantly rural catchment consists almost entirely of ground beneath $150 \mathrm{~m}$ above ordnance datum (AOD), with established forestry in the upper catchment (the first Ordnance Survey map (1879) identifies comparable levels of forest coverage) and occasional settlements as previously identified (Fig. 1; Gallois, 1965). There are only few notable impoundment structures within the system, the exceptions being Ardingly Reservoir (impounding ca. $20 \mathrm{~km}^{2}$ ) in the headwaters of the Ouse (constructed in 1978) and the Ashdown and Barcombe reservoirs, located between the forest of St Leonards and in the lowland floodplain (ca. $5 \mathrm{~km}$ upstream of Lewes). Mean high water is $3.5 \mathrm{~km}$ downstream of Lewes, with the tidal limit at Barcombe Mills (ca. $6.5 \mathrm{~km}$ upstream of Lewes), above the confluence of the Sussex Ouse and River Uck. The lower Sussex Ouse valley consists of thick alluvium overlying chalk with several prominent oxbows within the meandering river section, with an underlying mixed geology and permeable outcrops, particularly at the Tunbridge Wells Sands and Hastings Beds in the upper Uck (Marsh and Hannaford, 2008).

The distribution of precipitation across the Sussex Ouse catchment is determined largely by elevation, with northern sections of the catchment along the South Downs receiving a little over $1000 \mathrm{~mm} \mathrm{a}^{-1}$, compared to the coastal region which receives around $730 \mathrm{~mm} \mathrm{a}^{-1}\left(729 \mathrm{~mm} \mathrm{a}^{-1}\right.$ at Bexhill meteorological station, just to the east of the Sussex Ouse catchment on the coast (Mayes, 1997, pp. 73f).

In addition to the flood risk from the Sussex Ouse, the town of Lewes is also at risk of flooding from the Winterbourne Stream which emerges from the chalk aquifer during periods of high groundwater and as such can flood in combination with, or independently of, the Sussex Ouse.

\subsection{Channel management}

Eastwards longshore drift has continuously replenished the shingle spit at the mouth of the Ouse, resulting in intermittent phases where the Sussex Ouse has been relatively (un)impeded, resulting in inundation or draining of the Lewes Levels (Woodcock, 2003). In 1422 a Commission of Sewers was appointed to restore the banks and drainage between Fletching and the coast in an attempt to reduce flooding, but by the 1530 s the Lewes Levels, some 6000 acres $\left(24 \mathrm{~km}^{2}\right)$, had again returned to marshland (Brandon and Short, 1990). To counter this, in 1537 a water rate was levied on all lands on the Levels to fund the cutting of a channel through the shingle bar at the mouth of the Ouse to allow the river to drain the Levels, permitting the development of the sheltered harbour at Newhaven, succeeding the historic port of Seaford. The new channel temporarily drained the 
levels, but by the mid-17th century the Ouse was reported as unable to drain the levels and as being unfit for navigation; by the 18th century the valley was again regularly inundated throughout the summer months (Woodcock, 2003). In 1790 the Ouse Navigation Act was proposed, which would straighten (canalise) the Sussex Ouse at various points, new drainage structures would be created and a western breakwater added to reduce longshore drift and prevent sediment supply to the shingle spit. The eventual results of the canalisation was $35 \mathrm{~km}$ of canalisation channel, 19 locks and a $1.3 \mathrm{~km}$ branch added, with navigation up to Balcombe. However, the improved navigation failed to be a successful enterprise, with all trade above Lewes ceasing by 1868 , and navigation to Lewes only lasting until the 1950s. The consequence on the hydraulic capacity of the channel during high flow events is poorly detailed, though historical accounts (Table 1) continue to document overbank flooding during events comparable to that described by Pearce (2002) of extensive flood plain storage upstream of Lewes during flooding in 2000.

\subsection{Bridges of Lewes}

In central Lewes three bridges cross the Sussex Ouse: Willey's Bridge (a footbridge opened in 1965), the Phoenix Causeway (a larger road bridge built in the early 1970s), and Cliffe Bridge, which is much older and represents the sites of several historical bridges in Lewes (commonly known as Ouse Bridge; Fig. 2). In addition to the modern A27, a trunk road crosses the Sussex Ouse to the south of Lewes together with the adjacent railway bridge. The site of the modern-day Cliffe Bridge probably reflects the location of a ford, ferry or roman bridge (Dunvan, 1795; Salzman, 1940). Accounts detailing the repair of a bridge at the site exist from as far back as 1159 , with the bridge being rebuilt in 1561 and subsequently repaired in 1652, coinciding with accounts of extensive flooding (Dunvan, 1795). Historical accounts detail the bridge's destruction in 1726 (Sawyer, 1890), with the current bridge dating from 1727; consisting of a single stone arch structure, it was subsequently widened in 1932 (Salzman, 1940). The adjacent wharf was constructed in 17701771 and subsequently repaired in 1802 (Salzman, 1940), suggesting little change in the channel cross section at Lewes during the intervening period. The first Ordnance Survey map (1875) of Lewes shows little change in channel location and adjacent structures to the present day.

\section{Data sources, calibration and harmonisation}

Prior to the incorporation of historical data within flood frequency analysis, an assessment of the quality and reliability of the data must be made. Where possible, individual records should be checked by cross-referencing to coeval sources, When dealing with old accounts this is often challenging, but is valuable in identifying potentially spuri-

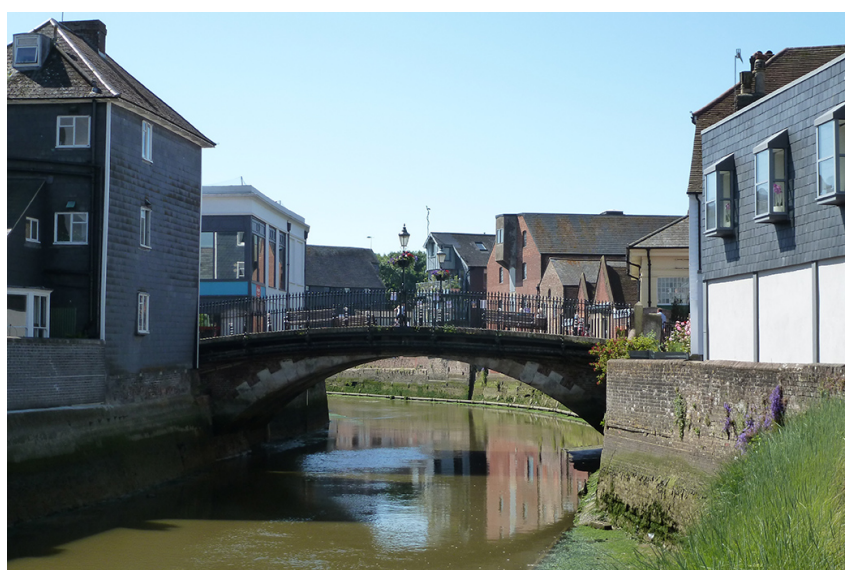

Figure 2. Ouse Bridge, central Lewes looking downstream (Amy Lennard).

ous events (Macdonald and Black, 2010). Where peak water levels or heights have been recorded, these should be critically assessed, preferably with conversion to a discharge where possible. Undertaking historical assessments can be time-consuming, and this is often cited along with lack of technical expertise as the main limitation to the inclusion of historical information in flood frequency analysis (Williams and Archer, 2002). Fortunately, the development of electronic databases such as the British Hydrological Society's Chronology of British Hydrological Events (CBHE) (Black and Law, 2004) and the French, Le répertoire des repères de crues (2013) permit searching to be undertaken quickly and efficiently. For the purposes of this study, the CBHE was used as an initial resource with subsequent research undertaken examining numerous independent source materials, including documentary records (e.g. British Rainfall), local histories and newspapers; a full discussion of the different historical sources available for such studies can be found in McEwen (1987) and Brazdil et al. (2012).

Inevitably the potential for modification to the channel cross section during the historical period represents a challenge when estimating historical flows, and consequently this study considers only the largest historical floods for the period since 1772. Although there are intermittent records available prior to this date, less confidence can be placed in the cross-sectional area of the channel at Lewes and floodgenerating mechanisms comparable to those of the present day. Greater confidence can be placed in the completeness of the records after ca. 1750-1800, however, a time frame comparable to that selected in previous studies (Parent and Bernier, 2003; Macdonald, 2013). In this study estimates are derived using a stage-discharge relationship for Lewes, as previous work (Macdonald and Black, 2010) has suggested that during the largest flows, relatively minor modifications within the channel and catchment may have minimal impact on flood discharge. Table 1 shows the largest flood events 
Table 1. Historical floods in the Sussex Ouse.

\begin{tabular}{|c|c|c|c|}
\hline Date & Account & Source & $\begin{array}{l}\text { Estimated } \\
\text { discharge } \\
\left(\mathrm{m}^{3} \mathrm{~s}^{-1}\right)\end{array}$ \\
\hline January 1772 & $\begin{array}{l}\text { Lewes: "The floods of January } 1772 \text { saw boats floating round the Bear Inn } \\
\text { adjoining the bridge ..." }\end{array}$ & Rector (1961) & 235 \\
\hline December 1801 & $\begin{array}{l}\text { Lewes: "in December } 1801 \text { the floodwaters nearly caused a disastrous fire in Swing- } \\
\text { pump Alley (now North Court) when they entered a building containing a quantity } \\
\text { of slaked lime. The blaze was formidable, but was soon brought under control ..." }\end{array}$ & Rector (1961) & 175 \\
\hline November 1810 & $\begin{array}{l}\text { "When the rainfall is very great, the low districts in the county [Sussex] become } \\
\text { flooded. The chief places thus inundated are the levels around Pulborough, Arundel, } \\
\text { Bramber, Beeding, Henfield, Lewes and Pevensey. In November, 1810, these places } \\
\text { were flooded, and at Arundel the water was seven feet deep in the levels ..." }\end{array}$ & Symons (1872), p. 164 & 100 \\
\hline December 1839 & $\begin{array}{l}\text { "When the rainfall is very great, the low districts in the county become flooded. The } \\
\text { chief places thus inundated are the levels around Pulborough, Arundel, Bramber, } \\
\text { Beeding, Henfield, Lewes and Pevensey. ... in December, 1839, severe floods..." }\end{array}$ & Symons (1872), p. 164 & 130 \\
\hline Autumn 1841 & $\begin{array}{l}\text { "When the rainfall is very great, the low districts in the county become flooded. The } \\
\text { chief places thus inundated are the levels around Pulborough, Arundel, Bramber, } \\
\text { Beeding, Henfield, Lewes and Pevensey. ... from October to December, 1841, and } \\
\text { in February, 1847, floods were caused by the melting of snow". }\end{array}$ & Symons (1872), p. 164 & 130 \\
\hline 31 October 1852 & $\begin{array}{l}\text { "The heavy and long-continued rains have produced disastrous floods in all parts of } \\
\text { the country. The local journals are filled with accounts of inundations, which have } \\
\text { destroyed the fruits of rural industry to a vast amount and occasioned incalculable } \\
\text { damage. At Lewes, the torrents which poured down from the hills covered the face } \\
\text { of the low ground for miles - boats were seen traversing the meadows; the traffic } \\
\text { on the railway was suspended, and the water burst into the cellars and overflooded } \\
\text { the streets in the lower part of the town. Stacks of corn and hay, planks, and rural } \\
\text { produce were carried away, and many sheep drowned". }\end{array}$ & Annual Register (1853) & 230 \\
\hline October 1852 & $\begin{array}{l}\text { Uckfield town: "Major flood events occurred in } 1852 \ldots \text { the information collated } \\
\text { was considered sufficiently robust to provide the following ranking for each of the } \\
\text { major floods during the last } 150 \text { years: Rank } 2-23 \text { October } 1852 \ldots \text { " }\end{array}$ & Macdonald (2004) & \\
\hline 26 October 1865 & $\begin{array}{l}\text { Uckfield town: "Major flood events occurred in ... } 1865 \ldots \text { the information collated } \\
\text { was considered sufficiently robust to provide the following ranking for each of the } \\
\text { major floods during the last } 150 \text { years: Rank } 5-26 \text { October } 1865 \ldots \text { " }\end{array}$ & Macdonald (2004) & 150 \\
\hline 11 November 1875 & $\begin{array}{l}\text { Rainfall observer at Uckfield, Sussex [river Uck, tributary of the Sussex Ouse] was } \\
\text { noted as reporting "highest flood since 1852" }\end{array}$ & Symons (1875), p. 71 & 190 \\
\hline 11 November 1875 & $\begin{array}{l}\text { Uckfield town: "Major flood events occurred in } \ldots 1875 \ldots \text { the information collated } \\
\text { was considered sufficiently robust to provide the following ranking for each of the } \\
\text { major floods during the last } 150 \text { years: Rank } 3-11 \text { November } 1875 \ldots \text { ". }\end{array}$ & Macdonald (2004) & 190 \\
\hline January 1916 & Uckfield town: "Major flood events occurred in ...1916 ..." & Macdonald (2004) & 100 \\
\hline January 1925 & $\begin{array}{l}\text { Lewes: "... Again severe flooding occurred in January 1925, business premises in } \\
\text { Cliffe High Street being badly damaged". }\end{array}$ & Rector (1961) & 130 \\
\hline November 1960 & $\begin{array}{l}\text { Lewes: "Floods are an old story to Lewes. All through the years the lowlands around } \\
\text { the town have been prone to flooding and the people of Cliffe have suffered in partic- } \\
\text { ular. It is unusual however that, as in the case of the } 1960 \text { floods, the Winterbourne } \\
\text { Stream should become such a menace... The first week in November } 1960 \text { saw the } \\
\text { worst floods that Lewes experienced since } 1925 \text { ". }\end{array}$ & Rector (1961) & 165 \\
\hline
\end{tabular}

identified from the historical records for the Sussex Ouse at Lewes. Records from AD 1750 are included, but early records are not considered as they introduce uncertainty: many appear to be derived from a single descriptive source, with these accounts syndicated to other outlets or simply duplicated.
Harmonisation of data from the various sources is required prior to the augmentation of the historical data and the gauged series. At Lewes two types of record are present:

1. discharges from Isfield and Gold Bridge gauging station in $\mathrm{m}^{3} \mathrm{~s}^{-1}$ (1960-present) 
2. historical accounts of flooding from documentary sources which provide detailed descriptive accounts of past flood extent and therefore level.

In the following sections a combined record will be created consisting of annual maximum (AMAX) flood peaks from the recorded discharge series and the historical accounts.

\subsection{Gauged flood data on the Sussex Ouse}

The series used within this study is a combination of two series, as no gauged series is available for the town of Lewes itself. The tidal limit on the Sussex Ouse is above the town of Lewes, as such there is potential for tidal influence during low flows, but the potential implications for flood events are limited. The combined series uses data from two stations, Gold Bridge on the Ouse $\left(41005 ; 180.9 \mathrm{~km}^{2}\right)$ and Isfield on the River Uck (41006; $87.8 \mathrm{~km}^{2}$ ), a tributary flowing into the Ouse between Lewes and Gold Bridge; with few flows entering the system between the town and Ouse Bridge (Longford Stream and Bevern Stream have maximum discharges of $4 \mathrm{~m}^{3} \mathrm{~s}^{-1}$ (estimated) and $5.36 \mathrm{~m}^{3} \mathrm{~s}^{-1}$ respectively, from an area of ca. $100 \mathrm{~km}^{2}$ ). The Maximum daily flow (MDF) data from the two sites were extracted from the UK Hiflows database (NRFA, 2014), with gaps filled with data held by the National River Flow Archives (NRFA, CEH Wallingford). This provided a complete series for Gold Bridge from 1960 and from Isfield from 1964. The combined series is shown in Fig. 3, alongside the historical data dating back to 1772 . To generate a single comparable AMAX series, the instantaneous peak flow (IPF) for the two stations were added together where they occurred within 1 day (time of peak is not recorded). Where no IPF is available for one of the stations maximum daily flow from the NRFA was added to the IPF, and this may result in some underestimation of the total discharge, but flows are unlikely to have been substantial if not recorded within the IPF series. An estimated discharge for the large flood on the River Uck in 1960 is available (ca. $100-120 \mathrm{~m}^{3} \mathrm{~s}^{-1}$ ) which can be combined with the discharge from Gold Bridge to generate an estimated flow at Lewes of $165 \mathrm{~m}^{3} \mathrm{~s}^{-1}$. At first glance, the largest flows $>150 \mathrm{~m}^{3} \mathrm{~s}^{-1}$ appear to have a similar frequency, though a much greater number of flows between 80 and $125 \mathrm{~m}^{3} \mathrm{~s}^{-1}$ are recorded within the instrumental period.

\subsection{Historical floods of the Sussex Ouse}

Past flood events along the Sussex Ouse are well documented in historical records, with some of the earliest accounts detailing flooding from a combination of fluvial and coastal sources: By the early fourteenth century, highlyprized meadow had been inned and embanked but its value was increasingly reduced by the recurrent inundations during the later middle ages resulting from the fall in the relative level of land to sea and the increased storm-tide frequency. Despite the raising of the banks, winter flooding was com-

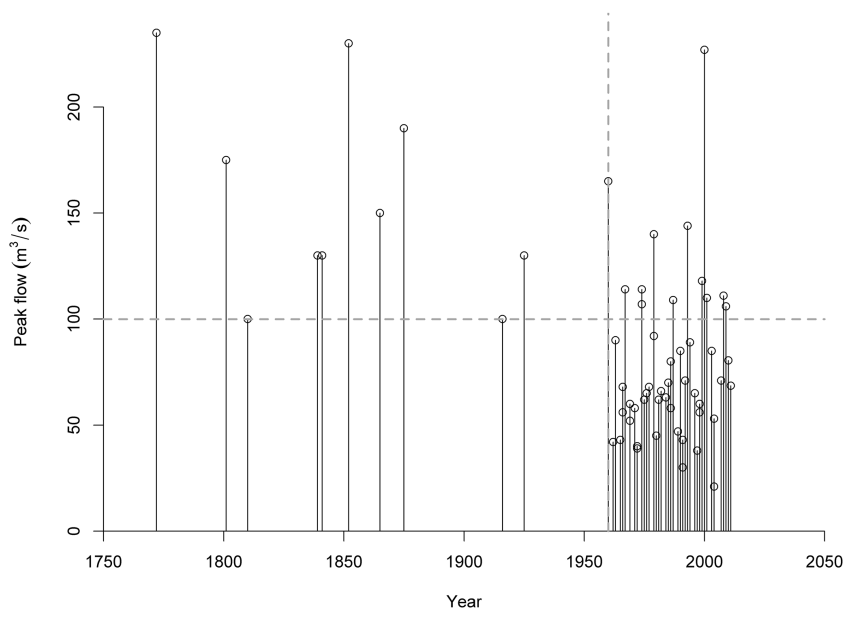

Figure 3. Combined historical and gauged series of AMAX events for the Sussex Ouse at Lewes.

mon in the fourteenth century and frequently the flood waters remained throughout the summer on the lower meadows and occasionally submerged crops on the bordering flanks (Glynde, 1996).

Many of the earliest accounts are concerned primarily with droughts, particularly those of the mid-14th century. This is unusual for most British catchments, where floods dominate the early records. The earliest account to detail flooding in Lewes specifically comes from the AD 1772 flood, in which "the floods of January 1772 saw boats floating round the Bear Inn adjoining the bridge" (Rector, 1961, p. 240). The descriptions provided by accounts often reflect on similar aspects, during the 1852 flood in Lewes a local newspaper, the Morning Chronicle, in part of its description details that "boats were rowing and sailing about" (Anon, 1852). The common reference to floating boats affords a degree of comparison between this event and the earlier event of 1772 to be made.

Historical accounts can also provide useful information on the effects of floods; these can help shape understanding of past responses and cultural practices in the face of such events (McEwen et al., 2013). For example, Rector (1961, p. 240) reports that "in December 1801 the floodwaters nearly caused a disastrous fire in Swing-pump Alley [now North Court] when they entered a building containing a quantity of slaked lime. The blaze was formidable, but was soon brought under control". Unlike at other sites where historical accounts detail flood events back to the 13th century (e.g. Macdonald, 2013), no such accounts exist at Lewes from which estimates of flood magnitude can be made. The earliest stems from 1772, which falls within the period for which there is reasonable confidence that all subsequent events exceeding a high threshold are known. 


\section{Winterbourne stream}

A number of floods affecting Lewes have originated from the Winterbourne Stream, which drains a small catchment $\left(18 \mathrm{~km}^{2}\right)$ to the west of Lewes. It is an ephemeral stream draining the Chalk Downs, and for much of its course it is culverted, emerging just downstream of Cliffe Bridge where it joins the Ouse, though historical accounts document that the lowland section was previously marsh, which flooded regularly in the spring. The catchment is now highly urbanised with several subsurface impoundment features included within the modern flood management structures. Historical floods are recorded prior to 1900 in 1772, 1801, 1814, 1829, 1852, 1875 and 1894 (Defra, 2008), affecting properties in several streets within the town, but not causing widespread flooding. Flood accounts within the historical records may reflect flooding from the Winterbourne rather than directly from the Ouse, and as such care should be taken in the interpretation of the historical accounts to consider this.

\section{Flood frequency analysis}

The inclusion of historical records inevitably involves the assumption that the AMAX values in the historical series would not be known unless they cross a certain perception threshold. It is also assumed that all events crossing the perception threshold will be known (Stedinger and Cohn, 1986). The selection of the threshold can be evaluated by considering the frequency of events above the threshold. The frequency of events recorded in the historical and gauged periods should ideally be comparable. More sophisticated techniques are available for assessing these assumptions (e.g. Renard et al., 2006). In the subsequent analysis two thresholds were considered: initially a threshold of $100 \mathrm{~m}^{3} \mathrm{~s}^{-1}$ was proposed that provided exceedance rates that were quite different between the historical and instrumental periods. Consequently, a threshold of $150 \mathrm{~m}^{3} \mathrm{~s}^{-1}$ was defined which produces sufficiently comparable exceedance rates between the two periods. For the purpose of this study, the second threshold will be used in subsequent analysis, though the issue of thresholds will be further developed in the discussion.

In the UK flood frequency analysis typically involves fitting a generalised logistic (GLO) distribution to annual maximum (AMAX) series of peak flow events using the method of L-moments as described in the Flood Estimation Handbook (IH, 1999); see Castellarin et al. (2012) for a more wide-ranging review of European statistical procedures applied in flood frequency analysis. However, no conclusive method has been developed within the L-moment framework for easily combining systematically gauged data with censored historical events in the historical period pre-dating the installation of a gauging station. Consequently, this study has adopted the probabilistic model for a censored AMAX series formulated as a maximum likelihood function as proposed by the Flood Studies Report (FSR), published by NERC (1975) and Stedinger and Cohn (1986) and previously applied for flood frequency analysis in selected British catchments by Archer (2010) using the GEV and GLO distributions. The model assumes that the AMAX events from both the gauged and the historical period are independent and follow the same distribution, which in this case is proposed to be the GLO distribution, with a probability density function $(\operatorname{pdf}-f(x))$ and a cumulative density function $(\operatorname{cdf}-F(x))$ defined as

$$
\begin{aligned}
& f_{x}(x)=\frac{\alpha^{-1} e^{-(1-\kappa) y}}{\left(1+e^{-y}\right)^{2}}, \\
& y=\left\{\begin{array}{l}
-\kappa^{-1} \ln (1-\kappa(x-\xi) / \alpha), \quad \text { when } \kappa \neq 0 \\
(x-\xi) / \alpha, \quad \text { when } \kappa=0
\end{array}\right. \\
& F_{x}(x)=\frac{1}{\left(1+e^{-y}\right)},
\end{aligned}
$$

where $\xi, \alpha$, and $\kappa$ are the location, scale and shape parameters, respectively. According to the value of the shape parameter $\kappa$, the value of $x$ is limited as follows: $-\infty<x \leq$ $\xi+\alpha / \kappa$ if $\kappa>0 ;-\infty<x<\infty$ if $\kappa=0 ; \xi+\alpha / \kappa<x<\infty$ if $\kappa<0$.

The record of AMAX events from the gauged record consists of $n$ events $\boldsymbol{x}=\left(x_{1}, x_{2} \ldots x_{n}\right)$, which are considered to be monitored with confidence across the entire flow regime, i.e. no censoring of these events is evident and no systematic/measurement error is present in the records. Next, historical events are only recorded if they are of a relevant magnitude, which is to say if they exceed the perception threshold value, $X_{0}$. A total of $k$ historical events $\boldsymbol{y}=\left(y_{1}, y_{2}, \ldots y_{k}\right)$ crosses the perception threshold over a total period of $h$ years, defined as stretching from the start of the historical record until the beginning of the systematic record. This leaves a total of $(h-k)$ years in the historical records for which the only information available on the AMAX event is that it did not exceed the perception threshold. For each year in the historical record the annual maximum exceeds the threshold with a probability $p=\left[1-F_{x}\left(X_{0}\right)\right]$ and the number, $k$, of threshold exceedances can be modelled as a binomial random variable $K \sim \operatorname{Bin}(h, p)$. In order to take into account not only the information that a large event occurred in the past, but also the calculated size of the historical events, the probability density function of the historical events is calculated. Since the size of a historical event is only known if it exceeded the perception threshold, the historical events above the threshold follow a conditional distribution $f_{x}\left(y \mid y>X_{0}\right)$. Considering that

$$
\begin{aligned}
f_{x}(y) & =f_{x}\left(y \mid y>X_{0}\right)\left[1-F_{x}\left(X_{0}\right)\right] \\
& +f_{x}\left(y \mid y \leq X_{0}\right) F_{x}\left(X_{0}\right) \\
& =f_{x}\left(y \mid y>X_{0}\right)\left[1-F_{x}\left(X_{0}\right)\right]
\end{aligned}
$$


and since $f_{x}\left(y \mid \leq X_{0}\right)=0$, the conditional distribution of the historical event can be rewritten as

$f_{x}\left(y \mid y>X_{0}\right)=\frac{f_{x}(y)}{1-F_{x}\left(X_{0}\right)}$.

Having defined the distribution for both gauged and historical data above, the full likelihood function describing the data series can now be defined as

$$
\begin{aligned}
L(\xi, \alpha, \kappa ; \boldsymbol{x}, \boldsymbol{y}) & =\underbrace{\prod_{i=1}^{n} f_{x}\left(x_{i}\right)}_{\mathrm{a}} \underbrace{\left\{\left(\begin{array}{l}
n \\
k
\end{array}\right) F_{x}\left(X_{0}\right)^{h-k}\left[1-F_{x}\left(X_{0}\right)\right]^{k}\right\}}_{\mathrm{b}} \\
\prod_{j=1}^{k} f_{x}\left(y_{j} \mid y_{j}>X_{0}\right) & \underbrace{}_{\mathrm{c}}
\end{aligned}
$$

where the three terms a-c represent contribution to the total likelihood function from the different data types: (a) gauged AMAX events, (b) the $h$ years in which the threshold $X_{0}$ was exceeded $k$ times, and (c) the distribution of the recorded historical events. By substituting Eq. (4) into Eq. (5), the likelihood function is simplified to include only the unconditional distribution, in other words

$L(\xi, \alpha, \kappa ; \boldsymbol{x}, \boldsymbol{y})=\prod_{i=1}^{n} f_{x}\left(x_{i}\right)\left(\begin{array}{l}n \\ k\end{array}\right) F_{x}\left(X_{0}\right)^{h-k} \prod_{j=1}^{k} f_{x}\left(y_{i}\right)$.

In the case where it is only known that an event exceeded the perception threshold, but the actual magnitude is not known, the last term of the likelihood function in Eq. (6) is changed to reflect this level of knowledge, in other words

$L(\xi, \alpha, \kappa ; \boldsymbol{x}, \boldsymbol{y})=\prod_{i=1}^{n} f_{x}\left(x_{i}\right)\left(\begin{array}{l}n \\ k\end{array}\right) F_{x}\left(X_{0}\right)^{h-k}\left[1-F_{x}\left(X_{0}\right)\right]^{k}$.

For both situations the three GLO parameters are estimated by maximising the value of the likelihood function in Eqs. (6) and (7) using numerical optimisation. The output from the maximum likelihood parameter fitting is a vector of the estimated parameter values $\hat{\boldsymbol{v}}=(\hat{\xi}, \hat{\alpha}, \hat{\kappa})$ and the associated covariance matrix $\boldsymbol{\Omega}$ where the elements represent the variancecovariance of the three estimated GLO parameters. The flood frequency curve is defined as the quantile function of the GLO distribution, which is itself the inverse of the cdf in Eq. (2), and from which the design flood event with a return period $T$ can be estimated as

$$
\begin{array}{ll}
\hat{x}_{T}=\hat{\xi}+\frac{\hat{\alpha}}{\hat{\kappa}}\left(1-(T-1)^{-\hat{\kappa}}\right) & \text { when } \kappa \neq 0 \\
\hat{x}_{T}=\hat{\xi}+\hat{\alpha} \ln (T) & \text { when } \kappa=0 .
\end{array}
$$

The total uncertainty of the estimated $T$ year flood will be made up by contributions from (1) sampling uncertainty by estimating model parameters from a limited number of data,
(2) model uncertainty because the GLO distribution might not provide a good description of the true underlying distribution and (3) uncertainty embedded in the reported values of the AMAX events of both gauged and historical data. In this study we will only consider the sampling uncertainty, but acknowledge that especially the data uncertainty and the difference between gauged and historical events could be a significant factor. Other researchers have developed more complex methods to more comprehensively capture the different uncertainty components, notably Gaume et al. (2010) and Neppel et al. (2010). However, the purpose of this study is to investigate the utility of the historical data, and the sampling uncertainty was considered adequate. The uncertainty related to the assumed distribution cannot be avoided and it is not expected that the effect of a model misspecification would be larger when using historical data combined with gauged data.

As the estimator in Eq. (8) is non-linear, the delta method is adopted to obtain a confidence interval for the $T$ years event. A Taylor expansion is used to obtain a linearised version from which the variance can be readily obtained as described by Kjeldsen and Jones (2006). Considering that the estimator $\hat{x}_{T}$ in Eq. (8) is an estimate of the true (unknown) value $x_{T}$ and is a function of a vector of estimated parameters, $\hat{\boldsymbol{v}}$ (whose true value is $\mathbf{v}$, thus $\hat{x}_{T}=g(\hat{\boldsymbol{v}})$ ), then the Taylor approximation gives

$\hat{x}_{T} \approx g(\mathbf{v})+\mathbf{d}^{T}(\hat{\boldsymbol{v}}-\mathbf{v})$,

where the elements $d_{i}$ in the vector $\mathbf{d}$ are given as $d_{i}=$ $\partial g / \partial v_{i}$ evaluated at $\mathbf{v}$. It then follows that the variance of the $T$ year event can be expressed as

$\operatorname{var}\left\{\hat{x}_{T}\right\} \approx \mathbf{d}^{T} \mathbf{\Omega d}$

Note that $\mathbf{d}^{T}$ in Eqs. (9) and (10) indicate the transpose of the vector $\mathbf{d}$ and has no relationship with the return period $T$. Having estimated the variance, the corresponding $95 \%$ confidence interval of the $T$ year event is obtained approximately, assuming the $T$ year event to be normally distributed, as plus and minus 2 times the standard deviation.

Rather than the standard numerical optimisation a Bayesian MCMC approach (as the one presented in Gaume et al., 2010) could be employed to maximise the equations in (6) or (7). These methods are readily available in the nsRFA library in $\mathrm{R}^{\mathrm{TM}}$ (Viglione, 2013). The advantage of using a Bayesian approach is that a full posterior distribution for the parameter estimates and any relevant quantity can be obtained, and no approximations like the ones in Eq. (10) are needed. The authors found, however, that little difference can be found in the final estimates, and that the BayesMCMC function can, in some cases, create computational issues or can be fairly slow to reach convergence. The interpretation of the results discussed in Sect. 5 would not change if Bayesian estimates were used. 
Table 2. Estimated GLO parameters, 100-year design flood and the associated standard deviation.

\begin{tabular}{|c|c|c|c|c|c|}
\hline \multirow[b]{2}{*}{ Method } & \multicolumn{3}{|c|}{ GLO parameters } & \multirow{2}{*}{$\begin{array}{c}x_{100} \\
\mathrm{~m}^{3} \mathrm{~s}^{-1}\end{array}$} & \multirow{2}{*}{$\begin{array}{l}\operatorname{sd}\left(x_{100}\right) \\
\mathrm{m}^{3} \mathrm{~s}^{-1}\end{array}$} \\
\hline & $\xi$ & $\alpha$ & $\kappa$ & & \\
\hline Single site & 69.5 & 17.7 & -0.28 & 234.8 & 39.9 \\
\hline $\begin{array}{l}\text { Historical data } \\
\text { of known magnitude }\end{array}$ & 68.0 & 15.9 & -0.23 & 197.3 & 21.6 \\
\hline $\begin{array}{l}\text { Historical data } \\
\text { of unknown magnitude }\end{array}$ & 68.1 & 15.9 & -0.23 & 196.3 & 23.2 \\
\hline
\end{tabular}

\section{Results}

The combined flood series for the Sussex Ouse consists of 5 historical floods (out of 10; Table 1) and 2 floods from the gauged series (1960 and 2000) which exceed the perception threshold of $150 \mathrm{~m}^{3} \mathrm{~s}^{-1}$. The historical record covers a period of 210 years starting in 1750 and ending in 1959, with the onset of data from systematic gauges initiated in 1960. The most recent water year included in the gauged series is 2010 (last event occurring 11 January 2011). For 2 years, 1962 and 2005, no MDF data are available and are considered missing. The gauged record therefore consists of 49 AMAX events observed over a period of 51 years, and thus the combined record covers a total period of 261 years (1750-2010) as shown in Fig. 3. In the subsequent flood frequency analysis for the Sussex Ouse at Lewes, three different methods will be assessed, reflecting three different levels of availability and confidence in the data set:

- single site analysis (Lewes) of the 49 AMAX events in the gauged record

- flood frequency analysis of the combined record, considering the peak discharge of the historical events to be exactly known

- flood frequency analysis of the combined record, considering the peak discharge of the historical events to be unknown, but known to exceed a defined perception threshold.

Finally, the impact of the level of the perception threshold will be conducted to assess the sensitivity of the method

\subsection{Flood frequency analysis}

For each of the three methods, the estimated parameters (location $\hat{\xi}$, scale $\hat{\alpha}$, shape $\hat{\kappa}$ ) of the GLO distribution are reported in Table 2 together with the estimated 100-year design flood and the associated standard deviation.

The fitted GLO models are plotted, including confidence intervals, against the observed AMAX in two different figures. Figure 4 shows the GLO distribution fitted directly to the 49 AMAX events in the gauged record. The position of the individual AMAX events in Fig. 4 is determined through

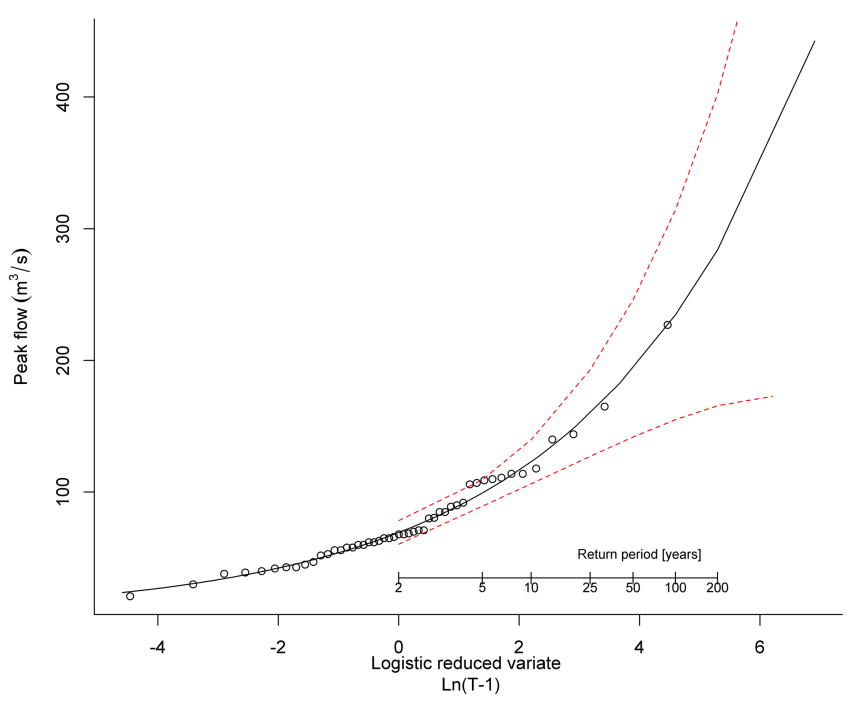

Figure 4. GLO distribution fitted to the 49 AMAX events from the gauged record (1960-2010) at Lewes with confidence limits at the $95 \%$ level.

use of the Gringorten plotting position. Figure 5 shows the GLO distribution fitted to the combined data series for the three cases (gauged only, known and unknown discharge of historical peak discharge). The plotting positions for the events in the combined record were calculated using the revised formula of Bayliss and Reed (2001). Note that introducing the historical floods will result in a different set of plotting positions being assigned to each of the events in the gauged record when compared to the set derived using the Gringorten methods on the gauged data only, thus the two plots in Figs. 4 and 5 show different positions of the gauged events on the flood frequency plots.

From the results in Table 2 it can be observed that the introduction of historical events has reduced the magnitude of the estimated 100-year event by $16 \%$, and at the same time reduced the standard error by $46 \%$ for the case where the historical events are assumed known, and by $42 \%$ when the peak discharge is unknown. These results illustrate that, for this case study, the inclusion of the historical evidence has resulted in a more precise estimate of the flood risk, thus highlighting the potential benefits of incorporating historical information into the flood frequency analysis.

\subsection{Sensitivity analysis}

A key assumption in the analysis is the definition of the perception threshold, $X_{0}$. In the flood frequency analysis documented in the previous section, a fixed perception threshold value of $X_{0}=150 \mathrm{~m}^{3} \mathrm{~s}^{-1}$ was adopted, which resulted in only 5 out of the 10 historical events being included into the analysis. To test the sensitivity of the results against the choice of threshold level, a sensitivity analysis was conducted by fitting a GLO distribution to a number of combined 


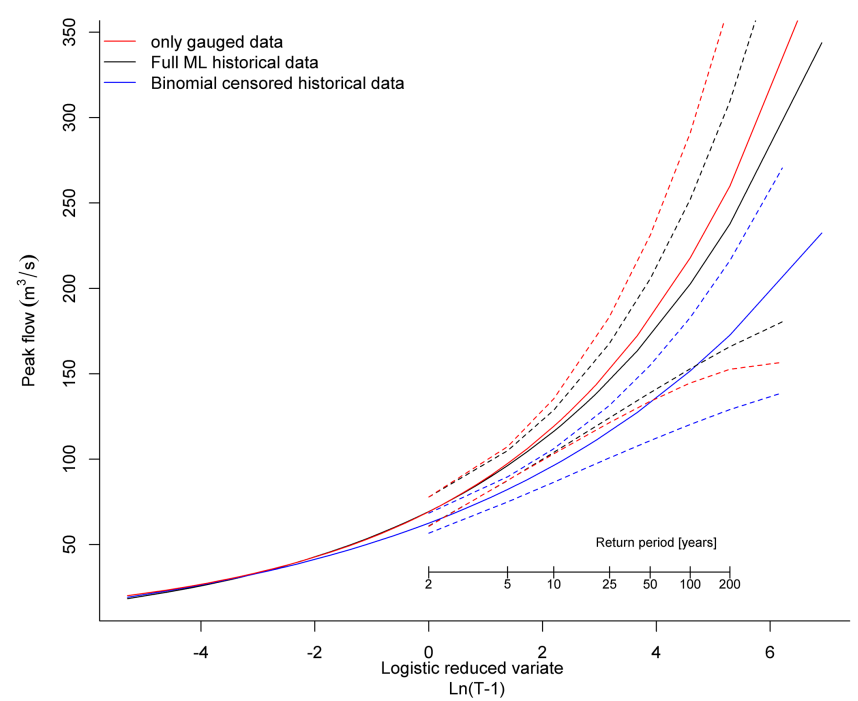

Figure 5. GLO distributions fitted to gauged data only, and the combined data series with historical events considering the peak discharge value to be known (full) and unknown (binomially censored). Hatched lines show the upper and lower $95 \%$ confidence intervals for the three different flood frequency curves.

data series, each containing the complete gauged series, but a varying number of historical events. The 10 historical events were ranked in ascending order, and the perception threshold defined to equal the discharge for each event in turn (or events where several events were found to have the same discharge). This resulted in a total of seven different combined data series based on perception threshold values of $X_{0}=100,130,150,175,190$, and $230 \mathrm{~m}^{3} \mathrm{~s}^{-1}$, where the lowest threshold of $X_{0}=100 \mathrm{~m}^{3} \mathrm{~s}^{-1}$ contains all 10 historical events, whereas the highest threshold value of $X_{0}=$ $230 \mathrm{~m}^{3} \mathrm{~s}^{-1}$ contains only the 1772 event in the historical data set.

It is noticeable that the flood frequency curve obtained when including all 10 historical events (curve 1 in Fig. 6) is visibly different from most other curves. The smallest historical flood magnitude in the series is $100 \mathrm{~m}^{3} \mathrm{~s}^{-1}$ (recorded in November 1810 and January 1916). In contrast, the number of events in the 51-year gauged record (1960-2010) exceeding the $100 \mathrm{~m}^{3} \mathrm{~s}^{-1}$ threshold is 12 , thus a comparison of the exceedance rate between the two series gives

- historical series: 10 events $>100 \mathrm{~m}^{3} \mathrm{~s}^{-1}$ in 210 years, rate $=0.05$ events/year

- gauged series: 12 events $>100 \mathrm{~m}^{3} \mathrm{~s}^{-1}$ in 51 years, rate $=0.23$ events/year.

While exceedance rate is only one aspect of a comparison, it is immediately clear that for such a low threshold value, substantially more historical events should have been identified before it could reasonably be concluded that the two data se-

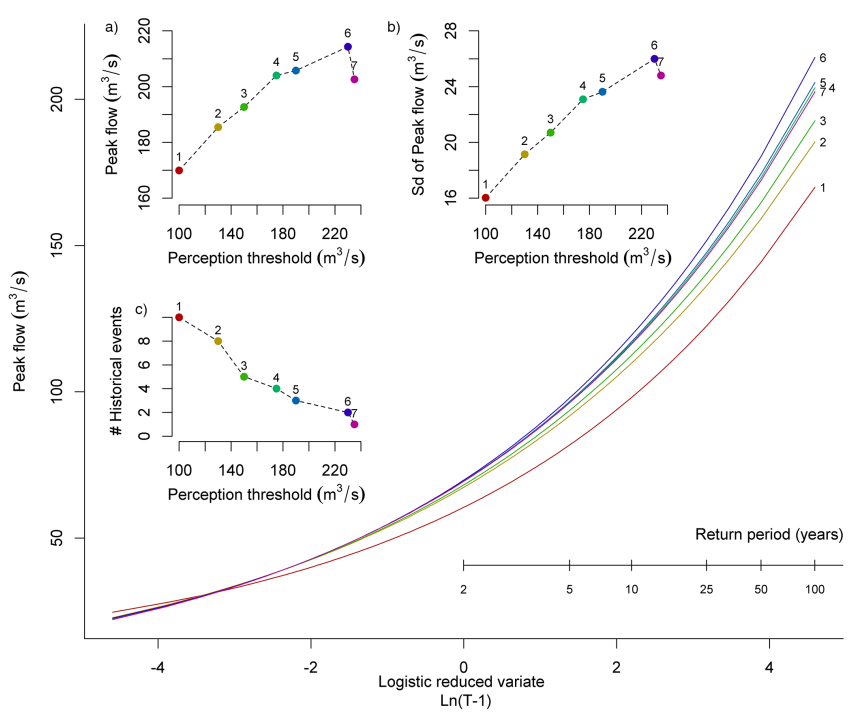

Figure 6. Sensitivity analysis of flood frequency curves fitted to the 49 gauged AMAX events combined with seven different threshold levels. The insert figures show the sensitivity of (a) the estimated 100-year design flood; (b) the standard deviation (SD) of the 100year design flood; and (c) the number of historical events used in the fitting. The numbers 1 to 7 in all graphs refers to the seven combined data series.

ries (historical and gauged) are both realisations of the same underlying distribution.

As the perception threshold increases, the difference between the estimated flood frequency curves becomes smaller, while the loss of data results in an increase in the standard deviation of the 100-year event. When only the one or two largest historical events are included, the resulting 100-year design flood estimate is relatively close to the estimates obtained from the gauged series alone, $235 \mathrm{~m}^{3} \mathrm{~s}^{-1}$ (see Table 2), while the standard deviation of the combined records are still substantially (about $43 \%$ ) below the $40 \mathrm{~m}^{3} \mathrm{~s}^{-1} \mathrm{ob}-$ tained from the use of the gauged series only. The strong differences that can be found when different perception thresholds are employed in the estimation procedure raise the question of the reliability of the estimated sizes of the historical events. In this study every effort has been made to assure a reliable set of historical data, but more modelling efforts can be made to include the uncertainties in the point estimates of the ungauged measures. See for example Neppel et al. (2010).

\section{Discussion}

The inclusion of historical information in augmenting instrumental series is dependent on the suitability, level of detail, reliability and availability of accounts, all of which are site specific. The selection of Lewes for this study was based on the identification of a historic settlement, but one which is based in a relatively small catchment, without a 
well-reconstructed flood history where no epigraphic markings (Macdonald, 2007) are present and which could be considered as representative of many catchments in the UK and elsewhere. This provided a valuable case study, as unlike many previous historical flood studies, it was not based on a historically significant city or on a river within a very large catchment. Threshold selection is a fundamental component within any analysis, with careful consideration required to ensure that there is compatibility between gauged and ungauged data series in the number of high-magnitude events, but as clearly shown the greater number of events included can have significant implications on the estimates derived, with a greater number of events reducing the associated magnitude of any specified design flood at Lewes (Fig. 6).

The inclusion of historical floods within a combined historical-instrumental flood series at Lewes reduces the uncertainty of design flood estimates of long return periods when compared to using just an instrumental flood series (Fig. 5). The differences between using exact discharges or knowing only that a historical event exceeded a perception threshold value has almost the same value. This is important as it indicates those events within the historical series where the discharge is unknown, but where they are known to exceed a specified threshold, inclusion provides valuable data; this supports the findings of Payrastre et al. (2011). This represents an important finding for future historical flood event inclusion and can be of significant assistance to those tasked with reconstructing historical flood series, as it identifies that specific discharges, whilst valuable, are not necessarily required with threshold exceedance but are a valuable tool when estimating high-magnitude events.

The use of historical flood information assumes that the generating mechanisms responsible for high-magnitude events have remained relatively stable over approximately the last 250 years (as shown by Macdonald, 2012 for NE England) and that land use is unlikely to have changed the capability of the catchment to produce and/or propagate large flood events (see Macdonald, 2012; Fouldes et al., 2013), or that the hydraulic properties of the channel have changed significantly during the intervening period (Herget and Meurs, 2010; Elleder et al., 2013). The evidence from Lewes suggests that these assumptions are fair to maintain, as the historical accounts and the maps and construction of the main channel features principally took place before or near the start of this period. The use of the historical records also reduces the likelihood of broader short-term phases which may be either flood-poor (1970-1990) or flood-rich (2000present), disproportionately affecting the return frequency estimates (see Macdonald and Black, 2010).

\section{Conclusions}

The principal finding of this research is that the inclusion of the largest historical events can have important implications on flood frequency estimation (Table 2). The approaches applied provide greater confidence in the derived estimates, with the historical records reducing the uncertainty for highmagnitude flood event estimation (>100-year return frequency), in this study by around $40 \%$. The use of historical information in a combination of approaches, for comparison and corroboration, together permit a more confident flood risk assessment at Lewes than would otherwise be possible.

The sensitivity of the application of threshold is important, with clear evidence that the selection of threshold, if set too low, can have a detrimental effect on the confidence of the derived flood frequency results as comparability between the series is undermined, but also if set too high has a lower impact on the estimates but can still lead to decreased uncertainty. Therefore, threshold selection remains a function of user expertise, though simply knowing that a flood event exceeded a threshold can have almost the same value in flood estimation as a specific estimate or series of estimates.

The findings of this paper support the call at both national (e.g. MARM, 2011; Miquel, 1984) and international (USWRC, 1982) levels for greater use of historical flood information in flood frequency analysis, as a means by which uncertainty can be reduced in high-magnitude flood estimation.

Acknowledgements. This research was in part funded by RGSIBG/EPSRC Geographical Research Grant EPSRC 3/05 to the first author. The authors would also like to thank the COST Action ES0901 for financial support. The authors would also like to thank the three anonymous reviewers for the details comments on the manuscript.

Edited by: A. Loukas

Reviewed by: D. Archer and two anonymous referees

\section{References}

Annual Register: Annual Register for 1852, Chronicle section. Published F. and J. Rivington, London, p. 184, 1853.

Anon: Great Flood at Lewes, The morning Chronicle (London), 6 October, Issue 26765, 1852.

Archer, D. R.: Applying historical information to Flood risk assessment in north-east England, BHS Third International Symposium, Managing Consequences of a Changing Global Environment, Newcastle, 2010.

Barriendos, M., Coeur, D., Lang, M., Llasat, M. C., Naulet, R., Lemaitre, F., and Barrera, A.: Stationarity analysis of historical flood series in France and Spain (14th-20th centuries), Nat. Hazards Earth Syst. Sci., 3, 583-592, doi:10.5194/nhess-3-5832003, 2003. 
Bayliss, A. C. and Reed, D. W.: The use of historical data in flood frequency estimation, Centre for Ecology \& Hydrology, Wallingford, UK, 87 pp., 2001.

Black, A. R. and Law, F.: Development and utilization of a national web-based chronology of hydrological events, Hydrol. Sci. J., 49, 237-246, 2004.

Böhm, O. and Wetzel, K-F.: Flood history of the Danube tributaries Lech and Islar in the Alpine foreland of Germany, Hydrol. Sci. J., 51, 784-798, 2006.

Brázdil, R., Glaser, R., Pfister, C., Dobrovolný, P., Antoine, J.-M., Barriendos, M., Camuffo, D., Deutsch, M., Enzi, S., Guidoboni, E., Kotyza, O., and Rodrigo, F. S.: Flood events of selected European rivers in the sixteenth century, Clim. Change, 43, 239-285, 1999.

Brázdil, R., Kundzewicz, Z. W., Benito, G, Demarée, G., Macdonald, N., and Roald, L. A.: Historical floods in Europe in the past millennium, in: Changes of Flood Risk in Europe, edited by: Kundzewicz, Z. W., Chap. 7, 121-168, IAHS Press, Wallingford, UK, 2012

Brandon, P. and Short, B.: The South-East from AD 1000, Longman, London, 1990.

Castellarin, A., Kohnová, S., Gaál, L., Fleig, A., Salinas, J. L., Toumazis, A., Kjeldsen, T. R., and Macdonald, N.: Review of applied-statistical methods for flood-frequency analysis in Europe, WG2 Report, COST Action ES0901 European Procedures for Flood Frequency Estimation, ISBN: 978-1-906698-324, 122 pp., 2012.

Defra: Department for Environment, Food and Rural Affairs: Lewes Integrated Urban Drainage Pilot Study Final Report - Volume 2, Defra Project Code TRE 344, Black \& Veatch, p. 152, 2008.

Dunvan, P.: Ancient and Modern History of Lewes and Brighthelmston: In which are compressed the most interesting events of the county at large, under the Regnian, Roman, Saxon and Norman Settlements, W. Lee, London, 1795.

Elleder, L., Herget, J., Roggenkamp, T., and Nießen, A.: Historic floods in the city of Prague - a reconstruction of peak discharges for 1481-1825 based on documentary sources, Hydrol. Res., 44, 202-214, 2013.

England, J. F., Jarrett, R. D., and Salas, J. D.: Data-based comparisons of moments estimators using historical and palaeoflood data, J. Hydrol., 278, 172-196, 2003.

Environment Agency: Sussex Ouse flood Management strategy Project Appraisal, Environment Agency, Southern Region, p. 8, 2004.

Gallois, R. W.: British Regional Geology: The Wealden District, Geological Survey and Museums, HMSO, London, 1965.

Glaser, R. and Stangl, H.: Historical floods in the Dutch Rhine Delta, Nat. Hazards Earth Syst. Sci., 3, 605-613, doi:10.5194/nhess-3-605-2003, 2003.

Glaser, R., Riemann, D., Schönbein, J., Barriendos, M., Brázdil, R., Bertolin, C., Camuffo, D., Deutsch, M., Dobrovolný, P., Engelen, A., Enzi, S., Halíčková, M., Koenig, S., Kotyza O., Limanówka, D., Macková, J., Sghedoni, M., Martin, B., and Himmelsbach, I.: The variability of European floods since AD 1500, Clim. Change, 101, 235-256, 2010.

Glynde, M. S.: in: Agriculture and the Effects of Floods and Weather at Barnhorne during the Late Middle Ages, edited by: Brandon, P. F., Sussex, Sussex Archaeological Collections, 109, p. $97,1996$.
Gaume, E., Gaál, L., Viglione, A., Szolgay, J., Kohnová, S., and Blöschl, G.: Bayesian MCMC approach to regional flood frequency analyses involving extraordinary flood events at ungauged sites, J. Hydrol., 394, 101-117, 2010.

Hannaford, J. and Marsh, T. J.: High-flow and flood trends in a network of undisturbed catchments in the UK, Int. J. Climatol., 28, 1325-1338, 2008

Herget, J. and Meurs, H.: Reconstructing peak discharges for historic flood levels in the city of Cologne, Germany, Global Planet. Change, 70, 108-116, 2010

Institute of Hydrology (IH): The Flood Estimation Handbook, Centre for Ecology and Hydrology, Wallingford, UK, 1999.

Kjeldsen, T. R. and Jones, D. A.: Prediction uncertainty in a median based index flood method using L-moments, Water Resour. Res., 42, W07414, doi:10.1029/2005WR004069, 2006.

Kundzewicz, Z. W., Szamałek, K., and Kowalczak, P.: The great Flood of 1997 in Poland, Hydrol. Sci. J., 24, 855-870, 1999.

Le répertoire des repères de crues, available at: http://www. reperesdecrues-seine.fr./carte.php, last access: 21 May, 2013.

Lewes District Council: Multi agency flood plan for Lewes, Lewes District Council and east Sussex County Council, Lewes, p. 51, 2010.

Macdonald, D. E.: Derivation of Design Flood Estimates for the River Uck near Uckfield - Problems and Solutions, Proc 39th Flood and Coastal Management Conf., York, 2004.

Macdonald, N.: Neil Macdonald on epigraphic records: a valuable resource in re-assessing flood risk and long-term climate variability, Environ. Hist., 12, 136-140, 2007.

Macdonald, N.: Trends in flood seasonality of the River Ouse (northern England), from archive and instrumental sources since AD 1600, Clim. Change, 110, 901-923, 2012.

Macdonald, N.: Reassessing flood frequency for the River Trent, Central England, since AD 1320, Hydrol. Res., 44, 215-233, 2013.

Macdonald, N. and Black, A. R.: Reassessment of flood frequency using historical information for the River Ouse, York, UK, Hydrol. Sci. J., 55, 1152-1162, 2010.

Macdonald, N., Black, A. R., Werritty, A., and McEwen, L. J.: Historical and pooled flood frequency analysis for the River Tay at Perth, Scotland, Area, 38, 34-46, 2006.

MARM: Guía metodológica para el desarrollo del Sistema Nacional de Cartografía de Zonas Inundables. Ministerio de Medio Ambiente y Medio Rural y Marino, Madrid, Spain, p. 349, 2011.

Marsh, T. J. and Hannaford, J. (Eds.): UK Hydrometric Register, Hydrological data Uk series Centre for Ecology and Hydrology, Wallingford, 200 pp., 2008.

Mayes, J.: South-East England, in: Regional Climates of the British Isles, edited by: Wheeler, D. and Mayes, J., Routledge, Abingdon, 67-88, 1997.

McEwen, L. J.: Sources for establishing a historic flood chronology (pre-1940) within Scottish river catchments, Scot. Geogr. Mag., 103, 132-140, 1987.

McEwen, L. J. and Werritty, A.: The Muckle Spate of 1829: the physical and societal impact of a catastrophic flood on the River Findhorn, Scottish Highlands. T. I. Brit. Geogr., 32, 66-89, 2007.

McEwen, L., Reeves, D., Brice, J., Meadley, F., Lewes, K., and Macdonald, N.: Archiving flood memories of changing flood risk: interdisciplinary explorations around knowledge for resilience, J. Arts Commun., 4, 46-75, 2013. 
Miquel, J.: Guide pratique d'estimation des probabilités de crues, Ed. Eyrolles, p. 160, 1984.

Neppel, L., Renard, B., Lang, M., Ayral, P.-A., Coeur, D., Gaume, E., Jacob, N., Payrastre, O., Pobanz, K., and Vinet, F.: Flood frequency analysis using historical data: accounting for random and systematic errors, Hydrol. Sci. J., 55, 192-208, 2010.

Natural Environment Research Council (NERC): Flood Studies Report, London, UK, 1975.

National River Flow Archive (NRFA): HiFlows-UK dataset version 3.1.1, available at: http://www.ceh.ac.uk/data/nrfa/data/ peakflow_data.html, 2014.

O'Connor, J. E. and Costa, J. E.: The world's largest floods, past and present - Their causes and magnitudes: US Geological Survey Circular, 1254, p. 13, 2004.

Ordnance Survey: County Series 1:25000 Sussex, 1st Edn., HMSO, London, 1875.

Parent, E. and Bernier, J.: Bayesian POT modelling for historical data, J. Hydrol., 274, 95-108, 2003.

Payrastre, O., Gaume, E., and Andrieu, H.: Usefulness of historical information for flood frequency analyses: a case study, Water Resour. Res., 47, W08511, doi:10.1029/2010WR009812, 2011.

Pearce, J.: Hydrologist experiences in times of flood: Sussex 2000, BHS 8th National Hydrology 2000, Symposium, Birmingham, 2002.

Potter, H. R.: The use of historical records for the augmentation of hydrological data, Institute of Hydrology, Report No. 46, Wallingford, UK, 1978.

Rector, W. K.: Lewes Floods, 1960, Sussex Notes and Queries vol XV, No. 7, p. 240/1, 1961.

Renard, B., Lang, M., and Bois, P.: Statistical analysis of extreme events in a non-stationary context via a Bayesian framework, Stoch. Env. Res. Risk A., 21, 97-112, 2006.
Salzman, L. F.: The borough of Lewes: Introduction and history: A History of the County of Sussex, Vol. 7: The rape of Lewes, 7-19, 1940.

Sawyer, J.: Notes on the Ridge family, being some extracts from "A Book of Memorandums Kept by William Ridge", 1715-1785, Sussex Archaeological Collections, 37, p. 119, 1890.

Stedinger, J. R. and Cohn, T. A.: Flood frequency analysis with historical and Paleoflood information, Water Resour. Res., 22, 785793, 1986.

Symons: Monthly Meteorological Magazine September 1872, Edward Stanford, London, p. 164, 1872.

Symons: British Rainfall 1875, Edward Stanford, London, p. 71, 1875.

Szlávik, L. (Ed.): Az 1998. évi árváz [Flood of the year 1998]. Vízügyi Közlemények, 85, 216 pp., 2003.

Ulbrich, U., Brücher, T., Fink, A. H., Leckebusch, G. C., Krüger, A., and Pinto, J. G.: The central European floods of August 2002: Part 1 - Rainfall periods and flood development, Weather, 58, 371-377, 2003.

USWRC: Guidelines for determining flood flow frequency. Bulletin 17B of the United States Water Resources Committee, Washington D.C., USA, 1982.

Viglione, A.: nsRFA: Non-supervised regional frequency analysis, R package. Version 0.7-11, available at: http://cran.r-project.org/ web/packages/nsRFA (last access: May 2014), 2013.

Williams, A. and Archer, D.: The use of historical flood information in the English Midlands to improve risk assessment, Hydrol. Sci. J., 47, 67-76, 2002.

Woodcock, A.: The archaeological implications of coastal change in Sussex, in: The Archaeology of Sussex to AD2000, edited by: Rudling, D., 1-16, Heritage, University of Sussex, 2003. 